\title{
SALINITY AND WATER TEMPERATURE ASSESSMENT OF THE TIDAL MARSHES FROM THE W PORTUGUESE COAST, AS AN ECOLOGICAL TOOL TO PALAEOENVIRONMENTAL RECONSTRUCTIONS BASED ON FORAMINIFERA AND OSTRACODA ASSEMBLAGES
}

\author{
FRANCISCO FATELA $^{(1)(2)}$, JOÃO MORENO ${ }^{(1)(2)} \&$ M. CRISTINA CABRAL ${ }^{(1)(2)}$
}

Abstract:

Resumo:

A seasonal study of temperature and salinity of estuarine and sediment interstitial water of tidal marshes was undertaken along three estuaries of W Portuguese coast (Minho, Tejo and Mira).

The climatic N-S transition from wet Atlantic to Mediterranean features appear clearly imprinted in the distribution of tidal marsh assemblages, like foraminifera and ostracoda, mainly reflecting the water salinity gradient control. The Minho low estuary tidal marsh tends to be flooded by estuarine water ranging from $0.5 \%$ to $32 \%_{0}$ in each tide cycle, even during dry seasons. However, the marsh hydrological balance sustains a more stable environment where the salinity of interstitial water measurements yielded $8 \%$ to $16 \%$. In contrast the Tejo and Mira salt marsh flooding waters record a narrow range between $33 \%$ and $36 \%$, in spring, and between $29 \%$ and $36 \%$ in autumn. The climatic control of evaporation/ precipitation balance produces an enhanced salinity of marsh interstitial water, that can reach hypersaline conditions, with maximum records of 53\%o in Tejo and 48\% in Mira lower estuaries.

These environmental differences along the W Portuguese coast are recorded by the tidal marsh assemblages, namely foraminifera and ostracoda. In the low salinity Caminha salt marsh, living foraminifera are essentially composed by the agglutinated species Haplophragmoides manilaensis, Miliammina fusca, Pseudothurammina limnetis Psammosphaera sp. and Trochamminita salsa. The modern ostracoda assemblage includes Leptochytere baltica, Leptochytere psammophila, Leptocythere sp. A and Tuberoloxoconcha sp.1. In the Tejo and Mira salt marsh Ammonia beccarii, Ammonia tepida, Haynesina germanica, Jadammina macrescens, Trochammina inflata, are the dominant foraminifera and Loxoconcha malcomsoni, Terrestricythere cf. elisabethae, Tuberoloxoconcha cf. atlantica and Xestoleberis labiata prevail as well as many other more marine ostracoda species, such as Basslerites teres and Leptocythere fabaeformis.

This study highlights that the knowledge of driven ecological parameters of modern assemblages (usually preserved in fossil record), is fundamental to support reliable paleoclimatic and palaeoenvironmental reconstructions.

Keywords: salinity, tidal marshes, foraminifera, ostracoda, Portuguese W coast

Avaliação da salinidade e da temperatura da água nos sapais da costa Oeste de Portugal, na perspectiva da reconstrução paleoambiental com base na ecologia de Foraminíferos e Ostracodos

O registo sazonal da temperatura e da salinidade da água dos estuários e da água intersticial dos sedimentos de sapal nos rios Minho, Tejo e Mira, durante a enchente, integram o estudo das associações de foraminíferos e ostracodos actuais da costa Oeste de Portugal. Nestes trabalhos podemos observar a transição entre o padrão climático húmido do NO da Península Ibérica e o padrão mediterrâneo a SO.

O sapal do baixo estuário do rio Minho tende a ser inundado por águas com grande amplitude de salinidade, de $0.5 \%$ a $32 \%$ em cada ciclo de maré, que persiste mesmo nas estações mais secas. No entanto o balanço hidrológico do sapal contribui para um ambiente relativamente estável, onde os valores da salinidade da água intersticial variam entre $8 \%$ e $16 \%$.

No baixo estuário do rio Mira, a salinidade das águas que inundam os sapais durante a preia mar varia apenas entre $33 \%$ e $36 \%$, na Primavera, e entre $29 \%$ e $36 \%$ no Outono. O balanço da evaporação/ precipitação no contexto climático do Sul, produz um aumento da salinidade da água intersticial até à hipersalinidade, que atinge $53 \%$ nos sapais do Tejo e $48 \%$ nos do Mira.

Estas diferenças das condições ambientais ao longo da costa Oeste de Portugal estão reflectidas na composição das associações dos organismos de sapal, nomeadamente dos foraminíferos e dos ostracodos. Sob as condições de baixa salinidade registadas no sapal de Caminha, a biocenose de foraminíferos é composta essencialmente pelas espécies de carapaça aglutinada Haplophragmoides manilaensis, Miliammina fusca, Pseudothurammina limnetis Psammosphaera sp. e Trochamminita salsa. A associação dos ostracodos actuais inclui as espécies Leptochytere baltica, Leptocythere psammophila, Leptocythere sp. A e Tuberoloxoconcha sp. 1. Nos sapais do Tejo e do Mira as espécies Ammonia beccarii, A. tepida, Haynesina germanica, Jadammina macrescens, Trochammina inflata, dominam a associação de foraminíferos, enquanto Loxoconcha malcomsoni, Terrestricythere cf. elisabethae, Tuberoloxoconcha cf. atlantica e Xestoleberis labiata se destacam numa associação de ostracodos com diversidade de espécies de características mais marinhas, como Basslerites teres e Leptocythere fabaeformis.

A relação encontrada entre a salinidade e a composição das associações de foraminíferos e ostracodos, mostra que a caracterização dos factores ecológicos e das biocenoses (dos grupos que integram o registo fóssil) em análogos actuais, são determinantes para a reconstituição fiável da evolução paleoclimática e paleoambiental.

Palavras-Chave: salinidade, sapais, foraminíferos, ostracodos, Costa Oeste de Portugal

\footnotetext{
(1) IDL - Instituto Dom Luiz, Universidade de Lisboa, Campo Grande, 1749-016, Lisboa, Portugal. Autor correspondente: ffatela@fc.ul.pt

${ }^{(2)}$ Departamento de Geologia da Faculdade de Ciências da Universidade de Lisboa, Campo Grande, 1749-016, Lisboa, Portugal.
} 


\section{INTRODUCTION}

Estuaries are highly productive environments but they also undergo intense impacts of human activities during the last century. The intertidal fringe is often occupied by salt marshes that represent one of the most suitable environments to search for the record of regional and global forcing mechanisms. Actually the almost constant sedimentation, that builds these zones, often represents the most continuous post-glacial geological record available on shore (e.g. DAVIS \& FITZGERALD 2004).

Since the 1950s several researchers studied salt marshes aiming to define environmental proxies, like foraminifera and ostracoda, to be used in palaeoclimatic and palaeogeographic interpretations, namely within the context of global change evaluation (e.g. Phleger \& WALton 1950; PujOS 1971; SCOTT \& Medioli 1980; GeHRELS 1994; DE RIJK 1995; HAYWARD et al. 1999; CEARRETA et al. 2000, 2007; HORNE \& BOOMER 2000; SEN GUPTA 2002; HORTON \& EDWARDS 2006; MURRAY 2006; CABRAL \& LOUREIRO, 2013). Such applications of microfossils record rests upon the Principle of Actualism which states that the composition of the micro-organisms assemblages strongly depends on the environmental biotic and abiotic parameters thereby making them reliable proxies. Consequently, their interpretation must be supported by a robust and site specific data base built upon the study of temperature, salinity, $\mathrm{pH}$, dissolved oxygen, and $\mathrm{CaCO}_{3}$ content (among others) that constrains the distribution of modern living communities (e.g. MORENO et al. 2005, 2007; LEORRI et al. 2008; FATELA et al. 2009; LOUREIRO et al. 2009; VALENTE et al. 2009; CABRAL \& LOUREIRO 2013).

In this paper we present the results of synoptic measurements of estuarine and interstitial waters temperature and salinity seen as main ecological parameters to the control of living tidal marsh assemblages along the West Portuguese coast (e.g. MORENO et al. 2006, 2007; FATELA et al. 2007, 2009; CABRAL \& LOUREIRO 2013).

\section{REGIONAL SETTING}

The W coast of Portugal faces the NE Atlantic and develops approximately from $37^{\circ} 00^{\prime} \mathrm{N}$ to $41^{\circ}$ $50^{\prime} \mathrm{N}$ and between $8^{\circ} 40^{\prime} \mathrm{W}$ and $9^{\circ} 30^{\prime} \mathrm{W}$, over more than $700 \mathrm{~km}$ long, often interrupted by many estuaries. The estuaries of Minho, Tejo (Tagus) and Mira were selected from those where preserved tidal marshes can be found in the lower estuary section.

Tides present a semi-diurnal high-mesotidal regime along this coast. The tidal range varies between $2 \mathrm{~m}$, during neap waters, and almost $4 \mathrm{~m}$ in spring waters but the astronomical tide levels are often incremented by storm surges (TABORDA \& DIAS 1991).

The Minho River defines the political border with Spain along $77 \mathrm{~km}$, joining the regions of Minho and Galicia (Fig. 1) and discharging the sea through a barred estuary trending NNE-SSW. The dynamic tide is felt up to $40 \mathrm{~km}$ upstream, due to the large tidal range and to both the smoothness and low gradient of the Minho's outlet (ALVES 1996). The upstream limit of marine water influence is not consensual and disparate distances of 9 to $35 \mathrm{~km}$ have been found (BETTENCOURT et al. 2003; Moreno et al. 2005).

The Minho watershed spans over $17080 \mathrm{~km}^{2}$ of igneous and metamorphic rocks basement, draining the rainiest region of Portugal. The average annual precipitation is ca. $1600 \mathrm{~mm}$ but exceptionally may reach $3500 \mathrm{~mm}$ (FATELA et al. 2014). The yearly average fluvial discharge is about $300 \mathrm{~m}^{3} / \mathrm{s}$ and the winter peak discharge (December to March) usually exceeds $1000 \mathrm{~m}^{3} / \mathrm{s}$ (BETTENCOURT et al. 2003).

The Tejo river has one of the largest estuaries of Western Europe, covering more than $325 \mathrm{~km}^{2}$. Forty percent of this area emerges during low water spring. The hydrographical basin develops in Portugal and Spain over $81310 \mathrm{~km}^{2}$, occupied by a large variety of igneous, metamorphic, calcareous and detritic rocks. The average annual precipitation in the Portuguese sector of Tejo basin reaches ca. $900 \mathrm{~mm}$. The fluvial average discharge is around $300 \mathrm{~m}^{3} / \mathrm{s}$, but may range out between $250 \mathrm{~m}^{3} / \mathrm{s}$ and $5400 \mathrm{~m}^{3} / \mathrm{s}$ under extreme dry or wet conditions (BETTENCOURT et al. 2003; ARH_Tejo 2011).

The dynamic tidal effects are felt up to a distance of $80 \mathrm{~km}$ upstream and the salt edges reaches $50 \mathrm{~km}$ upstream under the average flux of $300 \mathrm{~m}^{3} / \mathrm{s}$ (BETTENCOURT et al. 2003).

Mira is an important river of SW Portugal whose hydrographical basin occupies an area of $1600 \mathrm{~km}^{2}$ of mostly greywakes, pelites, slates, schists and conglomerates. The estuary extends from the mouth to SSE for almost $40 \mathrm{~km}$ of incised meanders, passing Odemira, where the dynamic effect of tide completely felts down (ICNB 2008). Annual precipitation is around $645 \mathrm{~mm}$, with a monthly average between $2.6 \mathrm{~mm}$ and $103 \mathrm{~mm}$ recorded in a series of 75 years. However, $0 \mathrm{~mm}$ is frequently record in summer (ICNB 2008). The fluvial discharge ranges from $0 \mathrm{~m}^{3} / \mathrm{s}$ during dry summers to $500 \mathrm{~m}^{3} / \mathrm{s}$ in winter and spring rainy periods, leading to a yearly average fluvial discharge of $2.9 \mathrm{~m}^{3} / \mathrm{s}$. Tides are thus the main flow component in the Mira estuary (INAG 2011).

\section{METHODS}

Salinity and temperature of estuarine and sediment pore-water were measured along 3 low estuary transects in Minho (Pedras Ruivas - PR), Tejo (Rosário - Ros) and Mira (Ponte de Vila Nova de Mil Fontes - PMF) tidal marshes (Fig. 1), under spring and autumn season conditions. The interstitial water was allowed to seep and accumulate inside perforated PVC tubes previously inserted into the sediment to a depth of $40 \mathrm{~cm}$ below the surface, following De Rijk (1995), and covered with aluminium foil 


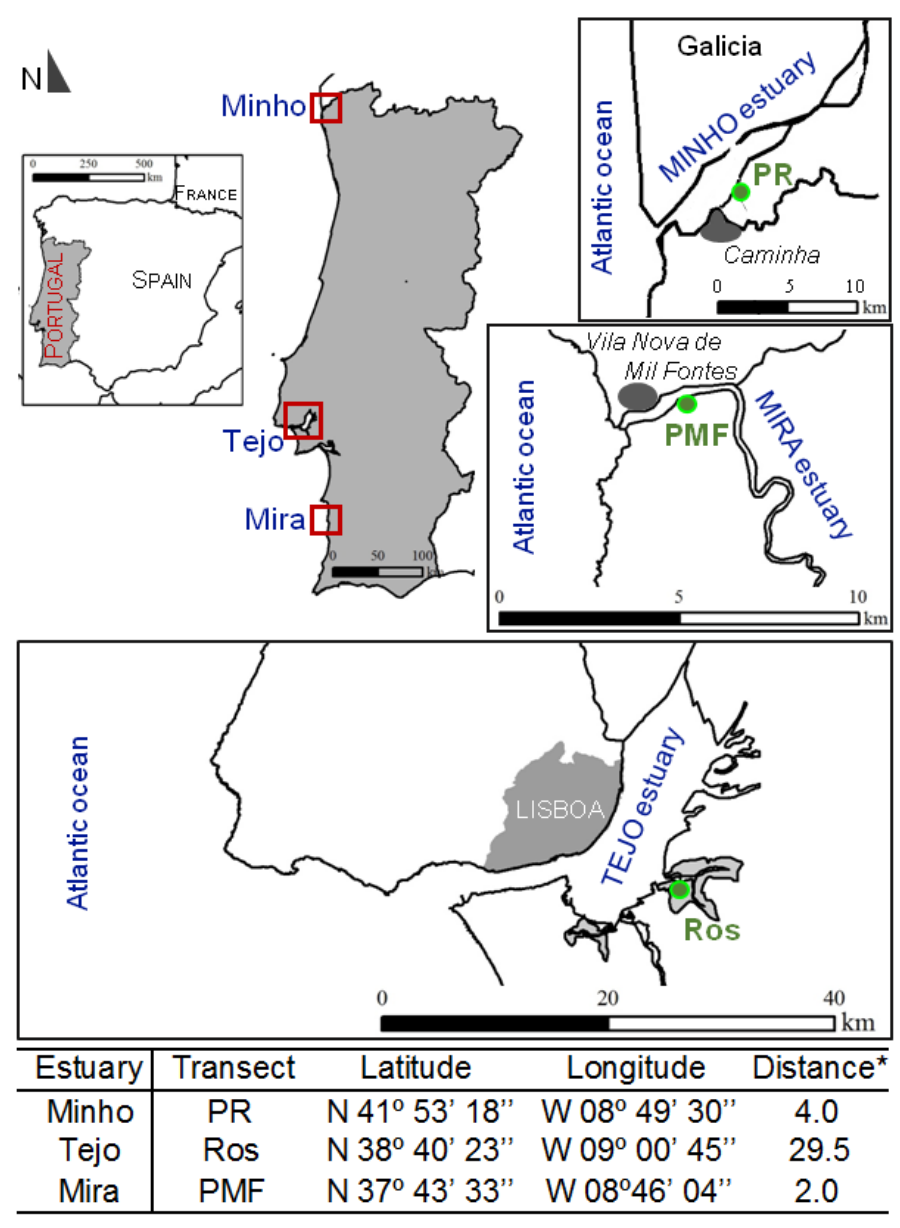

* Distance to river mouth $(\mathrm{km})$

Fig. 1. Location of studied salt marsh transects along the w coast of Portugal, in the estuaries of Minho (PR - Pedras Ruivas), Tejo (Ros - Rosário) and Mira (PMF - Ponte de Vila Nova de Mil Fontes).

Fig. 1. Localização dos sapais estudados ao longo da costa oeste de Portugal, nos estuários dos rios Minho (PR - Pedras Ruivas), Tejo (Ros - Rosário) and Mira (PMF - Ponte de Vila Nova de Mil Fontes).

between measurements. The salinity and temperature were also measured every 15 minutes, close to the marsh surface during the rising tide at PR (Minho) and PMF (Mira) transects. These measurements started just after the beginning of surface submersion and ended at high water slack, unless interrupted for safety reasons. Simultaneous measurement of the salinity and temperature of estuarine water has also been made close to the channel bottom, in high and low water during spring tide. Water parameters were measured using a multiparameters Horiba U-22, a WTW LF 191 and 197i probes. The water salinity terms of limnetic, oligohaline, mesohaline, polyhaline, euhaline and hypersaline, used hereafter, follow the criteria defined by the Venice System (1959).

The altimetric data of the sampling profiles have been obtained using a Zeiss Elta R55 total station from a bench mark connected to the national altimetric datum (Cascais), using the GPS differential positioning combined with a regional geoid model and linked to local chart datum (e.g. FATELA et al. 2009).

\section{RESULTS}

\subsection{Marsh sediment interstitial water}

\subsubsection{Minho estuary}

The temperature of Caminha marsh interstitial waters (PR) tend to have a stable pattern from tidal flat to high marsh. The main differences were found between spring (average: $11.5^{\circ} \mathrm{C}$ ) and autumn (average: $16.4^{\circ} \mathrm{C}$ ) temperatures, as shown in Table 1.

The salinity measurements in the PR transect (Fig. 2), under spring season conditions, yielded $0.9 \%$ in the subtidal domain, contrasting with low marsh values of $15.8 \%$ (PR5) and $7.7 \%$ of high marsh (PR10). This trend is maintained in autumn, but an increase in salinity values becomes clear (Fig. 2) with 1.9\%o in the subtidal domain and 9.4\%o in the high marsh (PR10). The maximum salinity of PR5 is the same as in spring but the other records of low marsh also arise (Tab. 1; Fig. 2). 
Table 1. Temperature and salinity of marsh sediment interstitial water and estuarine water. PR - Pedras Ruivas; Ros Rosário; PMF - Ponte de V.N. Mil Fontes; LT - low tide; HT - high tide.

Tabela 1. Temperatura e salinidade da água intersticial do sedimento de sapal e da água de estuário. PR - Pedras Ruivas; Ros Rosário; PMF - Ponte de V.N. Mil Fontes; LT - Baixa Mar; HT - Preia Mar.

\begin{tabular}{|c|c|c|c|c|c|c|c|c|c|c|c|c|c|}
\hline Tempe & ${ }^{\circ} \mathrm{C}$ & & & & & & & & & & & & \\
\hline \multirow{3}{*}{ MINHO } & \multirow{3}{*}{$\begin{array}{c}\text { Spring } \\
\text { Autumn }\end{array}$} & PR1 & PR2 & PR3 & PR4 & PR5 & PR6 & PR7 & PR8 & PR9 & PR10 & LT & HT \\
\hline & & & 11.9 & & & 11.7 & 12.1 & 11.3 & 10.3 & & & 11.8 & 13.4 \\
\hline & & & & & & 16.8 & 17.3 & 16.0 & 15.7 & & 15.9 & 15.0 & 18.4 \\
\hline \multirow{3}{*}{ TEJO } & \multirow{3}{*}{$\begin{array}{c}\text { Spring } \\
\text { Autumn }\end{array}$} & Ros1 & Ros2 & Ros3 & Ros4 & Ros5 & Ros6 & Ros7 & Ros8 & Ros9 & Ros10 & LT & HT \\
\hline & & 19.7 & & & 18.5 & & & & & 16.1 & & & \\
\hline & & & 15.2 & 14.4 & 14.0 & 14.5 & 12.6 & 14.1 & 14.3 & 13.7 & 13.6 & & 13.0 \\
\hline \multirow{3}{*}{ MIRA } & \multirow{3}{*}{$\begin{array}{c}\text { Spring } \\
\text { Autumn }\end{array}$} & PMF1 & PMF2 & PMF3 & PMF4 & PMF5 & PMF6 & PMF7 & PMF8 & PMF9 & PMF10 & LT & HT \\
\hline & & & & 16.9 & 17.2 & 16.1 & 16.3 & 14.7 & & & & 18.2 & 17.7 \\
\hline & & 16.3 & 16.0 & 15.2 & 15.1 & 14.9 & 14.5 & & & & & 15.7 & 17.0 \\
\hline \multicolumn{14}{|c|}{ Salinity $\%$} \\
\hline \multirow{3}{*}{ MINHO } & \multirow{3}{*}{$\begin{array}{c}\text { Spring } \\
\text { Autumn }\end{array}$} & PR1 & PR2 & PR3 & PR4 & PR5 & PR6 & PR7 & PR8 & PR9 & PR10 & LT & HT \\
\hline & & & 0.9 & & & 15.8 & 11.9 & 8.4 & 7.7 & & & 0.3 & 28.8 \\
\hline & & & & & & 15.8 & 14.4 & 12.2 & 10.4 & & 9.4 & 1.9 & 31 \\
\hline \multirow{3}{*}{ TEJO } & \multirow{3}{*}{$\begin{array}{c}\text { Spring } \\
\text { Autumn }\end{array}$} & Ros1 & Ros2 & Ros3 & Ros4 & Ros5 & Ros6 & Ros7 & Ros8 & Ros9 & Ros10 & LT & HT \\
\hline & & 28.0 & & & 32.9 & & & & & 40.4 & & & \\
\hline & & & 31.6 & 33.2 & 33.1 & 39.5 & 31.8 & 28.4 & 52.9 & 45.7 & 23.6 & & 29 \\
\hline \multirow{3}{*}{ MIRA } & \multirow{3}{*}{$\begin{array}{c}\text { Spring } \\
\text { Autumn }\end{array}$} & PMF1 & PMF2 & PMF3 & PMF4 & PMF5 & PMF6 & PMF7 & PMF8 & PMF9 & PMF10 & LT & HT \\
\hline & & & & 37.0 & 23.2 & 43.3 & 30.6 & 11.7 & & & & 32.8 & 35.8 \\
\hline & & 33.8 & 33.7 & 35.9 & 42.0 & 47.5 & 28.8 & & & & & 29 & 36 \\
\hline
\end{tabular}
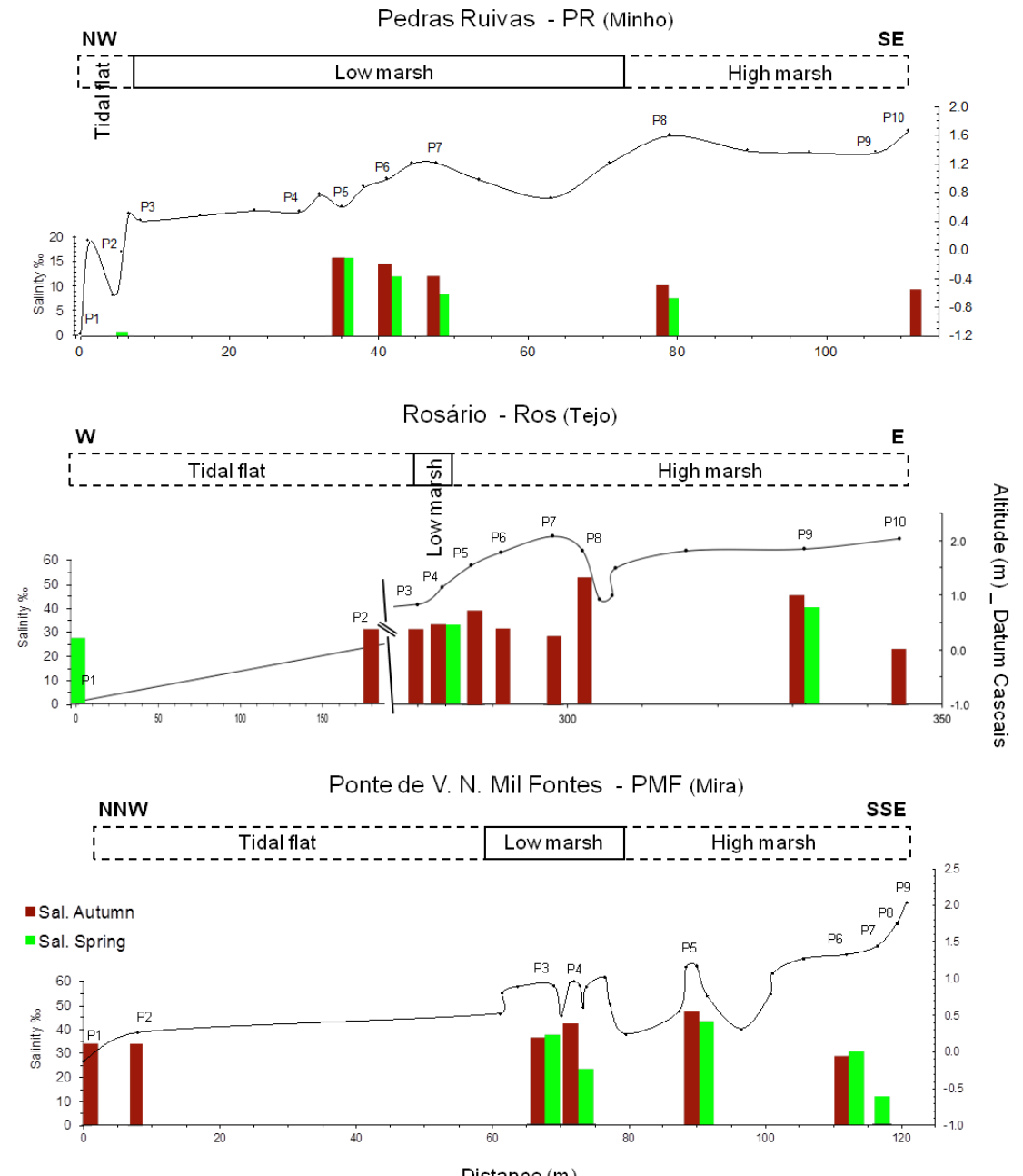

Fig. 2. Sampling profiles of studied transects of Pedras Ruivas (PR - Minho), Rosário (Ros - Tejo) and Ponte de V.N. Mil Fontes (PMF - Mira), showing the measured spring and autumn salinity of sediment interstitial water.

Fig. 2. Valores da salinidade da água intersticial do sedimento de sapal medidos, na Primavera e no Outono, nos perfis de amostragem de Pedras Ruivas (PR - Minho), Rosário (Ros - Tejo) e Ponte de V.N. Mil Fontes (PMF - Mira). 


\subsubsection{Tejo estuary}

At Rosário salt marsh the temperature of interstitial waters measured across the Ros transect is also very stable. The main differences are also related to season but reveal a reverse trend, when compared with Minho tidal marsh. The average temperature is higher in spring $\left(18.1^{\circ} \mathrm{C}\right)$ than in autumn $\left(14.0^{\circ} \mathrm{C}\right.$; Table 1$)$.

The salinity measurements in the Ros transect (Fig. 2), under spring season conditions, yielded $28 \%$ in the tidal flat (Ros1), $32.9 \%$ in the low marsh (Ros4) and 40.4\%o in the high marsh (Ros9). This direct relation of increasing salinity with altitude of the marsh surface is also clear in autumn (Fig. 2), ranging from $31.6 \%$ in the tidal flat (Ros2) and 52.9\% in the high marsh (Ros8). However, a significant drop to $23.6 \%$ is recorded at Ros10, in highest high marsh zone (Tab. 1).

\subsubsection{Mira estuary}

The stability of temperature in the marsh interstitial waters is also observed along the PMF transect (Tab. 1), with no significant difference between spring (average: $16.2^{\circ} \mathrm{C}$ ) and autumn (average: $15.3^{\circ} \mathrm{C}$ ) records.

The spring season salinity measurements in the PMF transect (Fig. 2), yielded $32.8 \%$ in the subtidal domain, an average of $30.1 \%$ in the low marsh and a maximum of $43.3 \%$ (PMF5) in the high marsh. The relation of increasing salinity with altitude of the marsh surface is also clear in this transect, rising in autumn (Fig. 2), except in the subtidal domain (33.8\%o). Average salinity record rises to $38.9 \%$ in the low marsh and reaches new maximum of $47.5 \%$ o (PMF5) in the high marsh. In both seasons a significant drop to $11.7 \%$ and $28.8 \%$, respectively, is recorded at the transition to highest high marsh zone (Tab. 1). All the sampling points from the highest high marsh were dry, in both spring and autumn campaigns, avoiding the measurement of interstitial water parameters.

\subsection{Tidal marsh flooding water}

\subsubsection{Minho estuary}

The Minho lower estuary records a wide range salinity twice a day (MORENO et al. 2005) resulting from the balance between river flow and tidal regime. The measurements close to the sediment surface across the PR transect, during its submersion by a spring tide, show that from the arrival of estuarine water at each sampling point until the complete flooding of the marsh, the salinity values at the sediment - water interface ranged from $0.5 \%$ to $31.6 \%$ in the tidal flat, $3.1 \%$ to $31.6 \%$ in the low marsh and $7.0 \%$ o to $23.1 \%$ in the high marsh (Fig. 3).

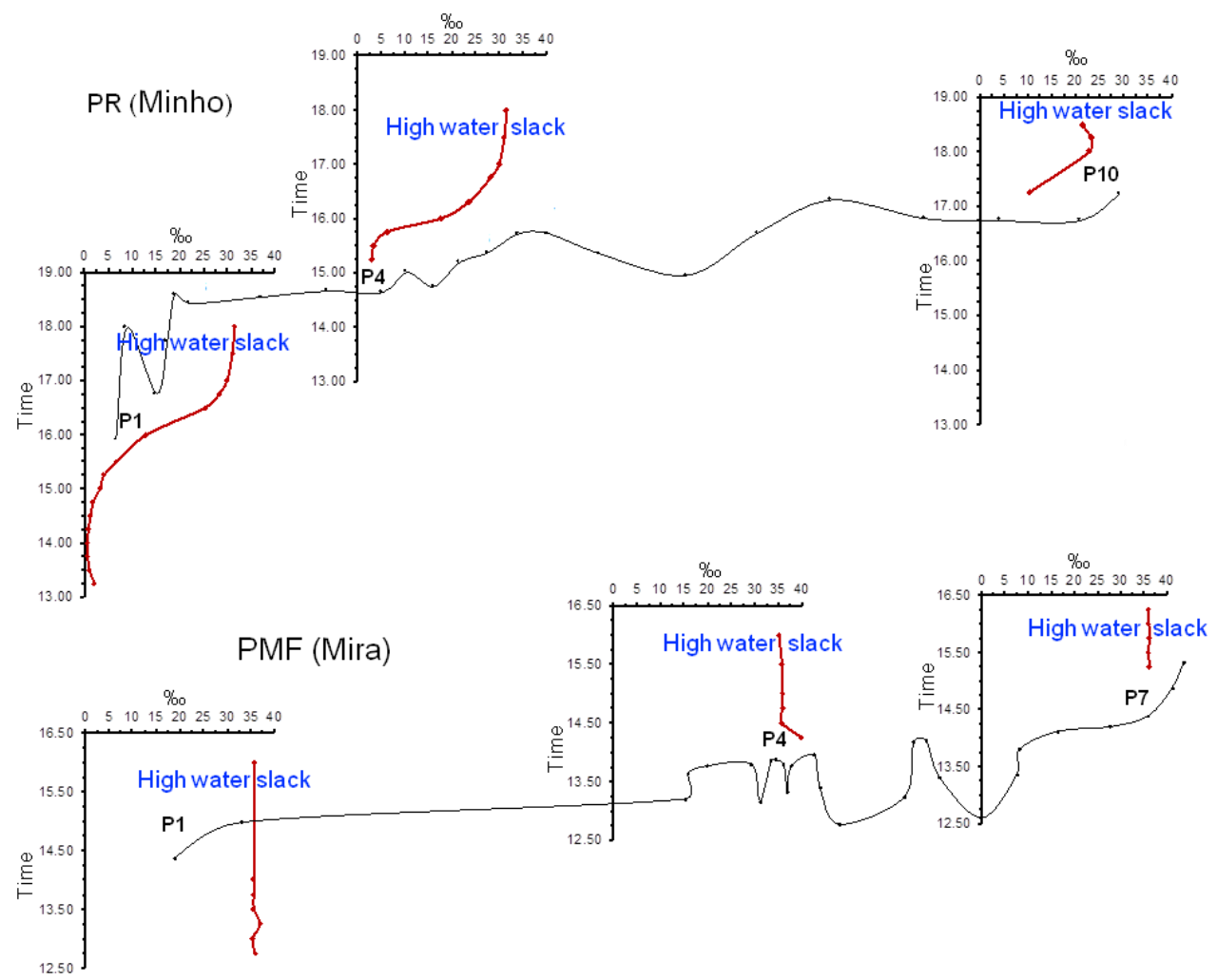

Fig. 3. Example of water salinity variation along tidal flat, low marsh and high marsh, during the spring tide flooding, in the Minho and Mira low estuaries.

Fig. 3. Exemplo da variação da salinidade ao longo da superfície do raso de maré, do baixo sapal e do alto sapal, durante a enchente duma maré de águas vivas, no estuário inferior dos rios Minho e Mira. 


\subsubsection{Mira estuary}

In the Mira lower estuary the tidal regime do not force a marked wide range of salinity. Our records show that in autumn the salinity ranges between $28.6 \%$ and $35.5 \%$, and between $32.8 \%$ and $35.8 \%$ in spring season.

The measurements performed during a rising spring tide across the PMF transect, show that from the arrival of estuarine water at each sampling point until the complete flooding of the marsh, the salinity values at the sediment - water interface range from $35.4 \%$ to $36.0 \%$ in the tidal flat, $35.0 \%$ to $39.8 \%$ in the low marsh and $35.4 \%$ o to $36.5 \%$ in the high marsh (Fig. 3).

\section{DISCUSSION}

A distinctive attribute of the $\mathrm{W}$ coast of Portugal is the transition from the warm and rainy Atlantic to the hot and dry Mediterranean climate across a distance of around $400 \mathrm{~km}$, in a narrow range of latitude. That means that estuarine environments and hydrographic basin are constrained by a $\mathrm{Cfb}$ climate type (temperate, with warm summer and no dry season) at North, and Csa climate type (temperate with hot and dry summers) at South (PEEL et al. 2007).

The temperature of marsh sediment interstitial waters is quite stable across all the transects for the same site and campaign. So when differences appear, they are directly connected with seasonality of climate in the temperate regions. The climatic fingerprint is also noted in the North to South increasing temperatures when the Caminha records are compared with Tejo and Mira marsh interstitial waters.

In the northern estuary of Minho River, the penetration of salt edge faces the resistance of lower basin morphology and of hydrological features resulting from the climate type mentioned above. On one hand, a widespread siltation has led to a very shallow estuary, with a very limited volume to hold the tidal prism. On the other hand, the intense and long precipitation regime generates a persistent run-off. In Summer, under spring tide conditions, the euhalyne water (30\% to $35 \%$ ) penetrates less than $5 \mathrm{~km}$ upstream during high tide (MORENO et al. 2005). However, at low tide the sea water is completely flush out, with prevailing oligohaline conditions $(0.5 \%$ to $5 \%$ ) all over the lower estuary (Fig. 4). In the rainy spring time, at spring high tide, the same domain is occupied by $29 \%$ to $26 \%$ waters (polyhaline), from the mouth to less than $5 \mathrm{~km}$ upstream. During low tide freshwater prevails and the most part of the estuary acquires limnetic conditions with $0 \%$ o to $0.5 \%$ (Fig. 4). Nevertheless, the daily salinity dynamic stress is considerably smoothed inside the marsh sediment. The salinity of tidal flooding waters is retained in the sediment pore water according to the submersion time, freshwater seepage from upland and evaporation/precipitation balance. In the Caminha tidal marsh the highest salinity (mesohaline) is found in the transition from low to high marsh zone (Fig. 3) as a result of a longer submersion with euhaline water. At the high water slack the top of high marsh tends to be flooded by polyhaline water, resulting from the less dense brackish mixture from Coura drainage, that is pushed onto the upland margin of Caminha tidal marsh. Moreover, interstitial high marsh water salinity is more affected by dilution with precipitation and freshwater inflow from surrounding land and groundwater.

In the Tejo and Mira marsh sediment interstitial waters the salinity values are higher than in Caminha tidal marsh. The low marshes of those southern estuaries are impregnated with euhalyne waters that became hypersaline in the high marsh. There is a clear direct relation between pore-water salinity and marsh surface altitude. However, altitude is not a factor by itself but reflects the true process reducing the time submersion by tidal flooding waters from tidal flat to the high marsh. After the tidal retreat the higher zones are exposed for a longer period where evaporation prevails due to the hotter and dryer season's conditions felt in southern estuaries.

The Mira lower estuary tends to preserve a body of euhalyne water even in low tides (BLANTON \& ANDRADE 2001). Under spring season conditions, low marsh may be covered by hypersaline water in the beginning of the flooding tide, tending to the euhalyne conditions in the high tide (Tab. 1; Fig. 3 ). This record reflects the importance of evaporation during low tide and the consequent precipitation of salt on the tidal flat and marsh surfaces. The rising tide dissolves this precipitated salt increasing significantly the salinity of the early flooding waters. By contrast in the Caminha tidal marsh we have recorded a gradual salinity increase, from limnetic to euhaline, in tidal flooding waters.

The Tejo and Mira salt marshes also record a relative decrease of pore-water salinity in the highest high marsh, suggesting that dilution by freshwater inflow from surrounding land and groundwater in the upland transition may be present under the dryer conditions of Csa climate type.

A seasonal cycle was found in the salinity of marsh interstitial water that leads to salt concentration in sediment during the dryer and hotter months (autumn records), and a dilution during the rainy and colder months (spring records), reflecting the evaporation/ precipitation balance along the $\mathrm{W}$ coast.

Salinity is very important for the metabolism of organisms, namely by osmosis (MURRAY 2006) and for the production of carbonated tests. This influence is very clear in the composition and distribution of foraminifera and ostracoda assemblages. They may tolerate a wide range of salinity, 

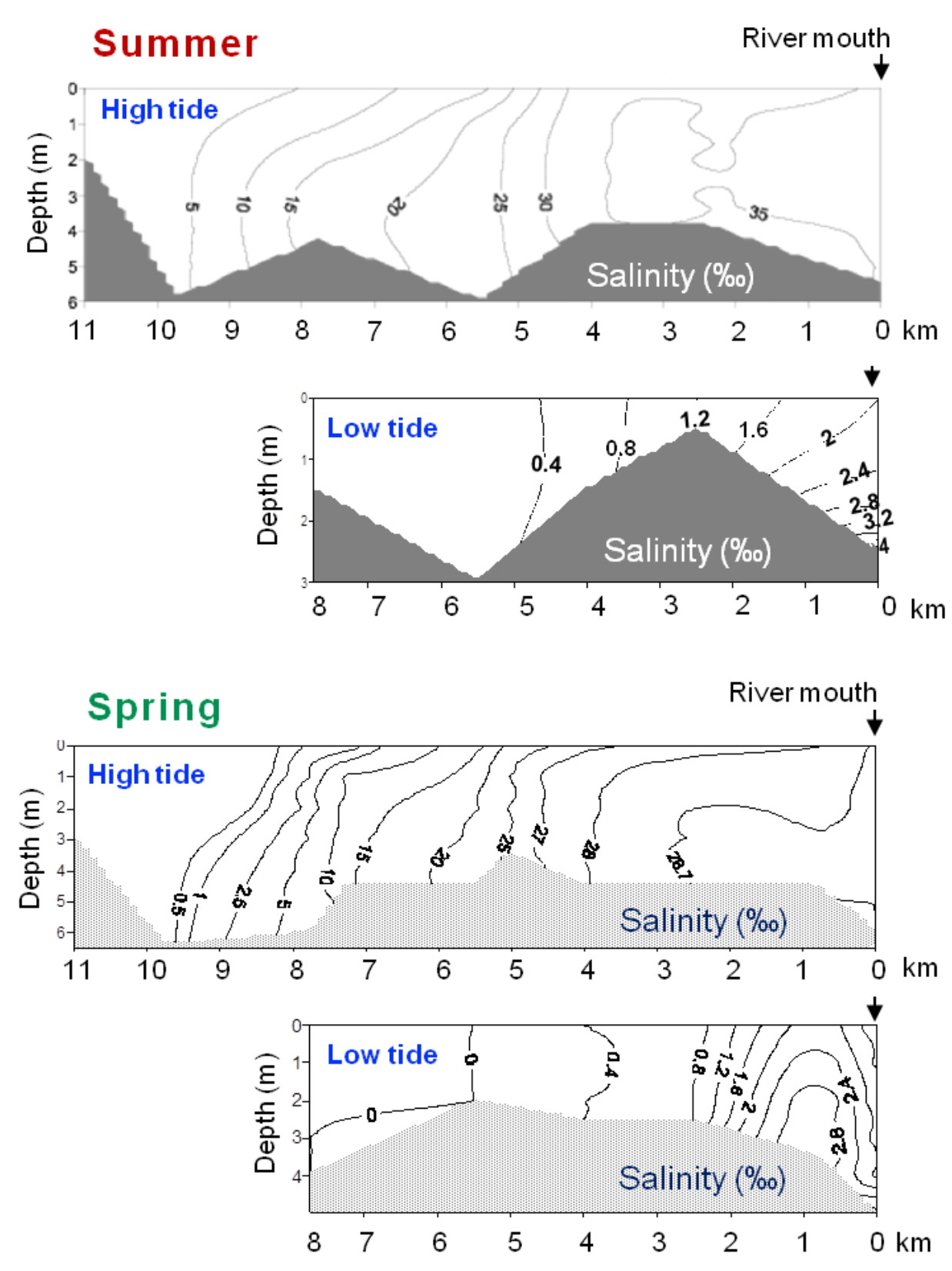

Fig. 4. Seasonal salinity profiles of Minho low estuary under summer and spring season conditions.

Fig. 4. Perfis sazonais da salinidade medida no estuário inferior do rio Minho, em situação de Verão e de Primavera.

from limnetic to hypersaline conditions, but most species are found under euhaline conditions where the assemblages exhibit the highest diversity (e.g. HAQ \& BOERSMA 1978; BOOMER \& EISENHAUER 2002; Sen GuPta 2002; FrenZel \& BOOMER 2005; MURRAY 2006).

The salt marsh foraminiferal assemblages under low salinity conditions are essentially composed by agglutinated species. For instance the Caminha salt marsh assemblages of living foraminifera include species like Haplophragmoides manilaensis Andersen, 1953, Miliammina fusca (Brady, 1870), Pseudothurammina limnetis (Scott and Medioli, 1980), Psammosphaera sp., Trocham- minita salsa/ irregularis (Cushman and Brönnimann, 1948) and Polysaccammina ipohalina Scott, 1976. When the salinity of marsh sediment rises till polyhaline to hypersaline conditions, as found in Tejo and Mira estuaries, they are replaced by Ammonia beccarii (Lineaus, 1758), A. tepida (Cushmann, 1926), Haynesina germanica (Ehrenberg, 1840), Jadammina macrescens (Brady, 1870), Trochammina inflata (Montagu,1808), Tiphotrocha comprimata (Cushman and Brönnimann, 1948), Paratrochammina guaratibaensis (Brönnimann, 1986) and Siphotrochammina lobata Saunders, 1957, among other minor species (e.g. HAYWARD et al., 1999; DEBENAY et al., 2000; SCOTT et al., 2001; SEN 
GUPTA, 2002; MORENO et al., 2006; FATELA et al., 2009, 2014). The same trend is clearly shown by Cabral and Loureiro (2013), among other authors, in the distribution of modern ostracoda assemblages. For instance, the brackish species found in Caminha tidal marsh, like Leptochytere baltica Klie, 1929, Leptocythere psammophila Guillaume, 1976, Leptocythere sp. A and Tuberoloxoconcha sp. 1 are replaced by a diverse assemblage in the Tejo and Mira salt marshes, under euhaline to hypersaline conditions, composed by Loxoconcha malcomsoni Horne and Robinson, 1985, Tuberoloxoconcha cf. atlantica Horne, 1989, Terrestricythere cf. elisabethae Horne, Smith, Whittaker and Murray, 2004, Xestoleberis labiata Brady and Robertson, 1874 and many other more marine species such as Basslerites teres (Brady, 1869) and Leptocythere fabaeformis (G. W. Müller, 1894) (e.g. LOUREIRO et al. 2009; CABRAL \& LOUREIRO 2013).

The knowledge of the influence of environmental parameters in the ecology of modern foraminifera, ostracoda, and many other groups, is a fundamental requirement to develop reliable palaeoenvironmental reconstructions.

\section{CONCLUSIONS}

The different climatic features recognized from the $\mathrm{N}$ to the $\mathrm{S}$ of Portugal, introduces significant differences in the hydrological balance of $\mathrm{W}$ coast estuaries. The contribution of freshwater drainage to the estuarine waters is reflected in the tidal marshes interstitial water parameters. The seasonal cycle is also well marked either the NW, under warm summers and no dry season (Cfb climate type) or the SW, under hot and dry summers (Csa climate type).

The tidal flooding waters that covers the salt marshes are not homogeneous. In the Minho low estuary the salinity may range between limnetic to euhaline conditions in the same tidal cycle. However, in the interstitial water mesohaline conditions prevail, under both the spring and autumn seasons, showing that tidal marsh may offer a relatively stable environment when compared with the extreme daily salinity variation of the lower estuary.

In contrast the Tejo and Mira salt marsh flooding waters tend to keep euhaline characteristics, although they can be slightly polyhaline in the rainy season. Such conditions and the control of evaporation/ precipitation balance are responsible by an enhanced euhaline to hypersaline interstitial marsh waters.

These environmental contrast are clearly reflected in the composition and distribution of tidal marsh assemblages. Namely foraminifera and ostracoda, that tend to be dominated by low salinity tolerant species in the low estuaries from NW and by high salinity tolerant species in the low estuaries of SW coast.

This data from Portuguese marshes represent a reliable support for the interpretation of the geological record in a regional, as well as global context, of palaeoclimatic and palaeoenvironmental reconstructions of east North Atlantic estuaries.

\section{ACKNOWLEDGMENTS}

This paper is a contribution of the MicroDyn (POCTI CTA/45185/2002) and WestLog (PTDC/CTE/105370/2008) projects, funded by the Fundação para a Ciência e Tecnologia - FCT. João Moreno benefits from a PhD grant (SFRH/ $\mathrm{BD} / 87995 / 2012$ ) from FCT. We would like to thank our colleagues Anabela Cruces, Filipa Moreno, João Cascalho, Catarina Fradique, Celso Pinto, Tanya Silveira, Francisca Rosa, Catarina Guerreiro, Vera Lopes, Raquel Cardoso and Ana Rita Figueiredo, among other for assistance laboratory and field work.

\section{REFERENCES}

Alves, A. 1996. Causas e Processos da Dinâmica Sedimentar na Evolução Actual do Litoral do Alto Minho. Unpublished $\mathrm{PhD}$ thesis, Univ. Minho, Braga, Portugal. 442 pp.

ARH Tejo, 2011. United Nations World Water Development Report. World Water Assessment Programme (UNESCO). The Tagus River Basin District - Portugal. Case Study. Edited by Ministério da Agricultura, Mar, Ambiente e Ordenamento do Território / Administração da Região Hidrográfica do Tejo I.P.

Bettencourt, A., Ramos, L., Gomes, V., Dias, J.M.A., Ferreira, G., Silva, M. \& CostA, L. 2003. Estuários Portugueses. Ed. INAG - Ministério das Cidades, Ordenamento do Território e Ambiente. Lisboa. $311 \mathrm{pp}$.

Blanton, J.O. \& Andrade, F.A. 2001. Distortion of tidal currents and the lateral transfer of salt in a shallow coastal plain estuary (O estuário do Mira, Portugal). Estuaries, 24: 467-480.

BoOmer, I. \& Eisenhauer, G. 2002. Ostracod faunas as palaeoenvironmental indicators in marginal marine environments. In: Holmes, J. A., Chivas, A. R. (Eds.). The Ostracoda applications in Quaternary Research. American Geophysical Union, Washington, DC, Geophysical Monograph, 131: 135-149.

Cabral, M. C. \& Loureiro, I. M., 2013. Overview of Recent and Holocene ostracods (Crustacea) from brackish and marine environments of Portugal Journal of Micropalaeontology, 32 (2): 135-159.

Cearreta, A., Irabien, M. J., Leorri, E., Yusta, I., Croudace, I. W. \& Cundy, A. B., 2000. Recent antropogenic impacts on the Bilbao estuary, $\mathrm{N}$. Spain: Geochemical and microfaunal evidence. Estuarine, Coastal and Shelf Science, 50: 571-592.

Cearreta, A., Alday, M., Freitas, M.C. \& Andrade, C., 2007. Postglacial foraminifera and paleoenvironments of the Melides Lagoon (SW Portugal): towards a regional model of coastal evolution. Journal of Foraminiferal Research, 37: 125-135.

DAVIS, R. JR. \& FitzGerAlD, D. 2004. Beaches and Coasts. Blackwell Publishing Company, 419 pp.

Debenay, J.-P., Guillou, J-J., Redois, F. \& Geslin, E. 2000. Distribution trends of foraminiferal assemblages in paralic environments - A base for using Foraminifera as bioindicators. In: Martin, R.E. 
Salinity and water temperature assessment of the tidal marshes from the W Portuguese coast, as an ecological tool to palaeoenvironmental reconstructions based on Foraminifera and Ostracoda assemblages

(Ed.), Environmental Micropaleontology - The Application of Microfossils to Environmental Geology. Kluwer Academic / Plenum Publishers: 39-67.

DE RIJK, S. 1995. Salinity control on the distribution of salt marsh Foraminifera (Great Marshes, Massachusetts). Journal of Foraminiferal Research, 25: 156-166.

Fatela, F., Moreno, J., Moreno, F., Araújo, M. F., VAlente, T., Antunes, C., TABorda, R., ANDRADE, C. \& DRAGO. T. 2009. Environmental constraints of foraminiferal assemblages distribution across a brackish tidal marsh (Caminha, NW Portugal). Marine Micropaleontology, 70 (1-2): 70-88.

Fatela, F., Moreno, J. \& Antunes, C. 2007. Salinity influence on foraminiferal tidal marsh assemblages of NW Portugal: an anthropogenic constraint? Thalassas, 23: 51-63.

Fatela, F., Moreno, J., Leorri, E. \& Corbett, R. 2014. High marsh foraminiferal assemblages response to intra-decadal and multi-decadal precipitation variability, between 1934 and 2010 (Caminha, NW Portugal). Journal of Sea Research, 93: 118-132.

Frenzel, P., Boomer, I. 2005. The use of ostracods from marginal marine, brackish waters as bioindicators of modern and Quaternary environmental change. Palaeogeography, Palaeoclimatology, Palaeoecology, 225: 68-92.

GEHRELS, W.R., 1994. Determining relative sea level change from salt marsh foraminifera and plant zones on the coast of Maine, USA. Journal of Coastal Research, 10: 990-1009.

HAQ, B.U. \& BOERSMA, A. 1978. Introduction to marine micropaleontology. Elsevier, 387pp.

Hayward, B.W., Grenfell, H.R., Reid, C., M. \& HayWARD, K.A. 1999. Recent New Zealand shallowwater benthic foraminifera: taxonomy, ecologic distribution, biogeography, and use in paleoenvironmental assessment. Institute of Geological \& Nuclear Sciences monograph, 21. Lower Hutt, New Zealand. 264 pp.

HoRne, D.J. \& BoOMER, I. 2000. The role of Ostracoda in saltmarsh meiofaunal communities. In: Sherwood, B.R., Gardiner, B.G. and Harris, T. (Eds), British Saltmarshes, Forrest Text, Cardigan, for the Linnean Society of London: 182-202.

Horton, B.P. \& EDWARds, R.J. 2006. Quantifying Holocene sea-level change using intertidal foraminifera: lessons from the British Isles. Cushman Foundation for Foraminiferal Research, sp. pub. 40, 97 pp.

ICNB, 2008. Plano de ordenamento do Parque Natural do Sudoeste Alentejano e Costa Vicentina; Estudo base - Etapa 1. Instituto da Conservação da Natureza e da Biodiversidade, $287 \mathrm{pp}$.

INAG, 2011. Instituto Nacional da Água (http:// www.inag.pt/estuarios/ MenusEstuarios/Descri\% C $3 \%$ A $7 \%$ C $3 \%$ A 3 o/descricao Mira.htm) 22.06.2011

Loureiro, I. M., Cabral, M. C. \& Fatela, F. 2009. Marine influence in Ostracod assemblages of the Mira River estuary: comparison between lower and mid estuary tidal marsh transects. Journal of Coastal Research, SI 56: 1365-1369.
Leorri, E., Horton B.P. \& Cearreta, A. 2008. Development of a Foraminifera-Based Transfer Function in the Basque Marshes, N. Spain: Implications for Sea -Level Studies in the Bay of Biscay. Marine Geology, 251: 60-74.

Moreno, J., Fatela, F., Andrade, C., Cascalho, J., Moreno, F. \& Drago, T. 2005. Living Foraminiferal assemblages from Minho/Coura estuary (Northern Portugal): a stressfull environment. Thalassas, 21: 17-28.

Moreno, J., Fatela. F., Andrade, C., \& Drago T. 2006. Distribution of "living" Pseudothurammina limnetis (Scott and Medioli): an occurence on the brackish tidal marsh of Minho/Coura estuary - Northern Portugal. Révue de Micropaléontologie, 49: 45-53.

Moreno, J., Valente, T., Moreno, F., Fatela, F., Guise, L., \& PATINHA C. 2007. Calcareous Foraminifera occurrence and calcite-carbonate equilibrium conditions - a case study in Minho/Coura estuary $(\mathrm{N}$ Portugal). Hydrobiologia, 597: 177-184.

MurRay, J.W., 2006. Ecology and Applications of Benthic Foraminifera. Cambridge University Press, 438 pp.

Peel, M. C. and Finlayson, B. L. \& McMahon, T. A. 2007. Updated world map of the Köppen-Geiger climate classification. Hydrology and Earth System Sciences, 11: 1633-1644.

Phleger, F.B. \& Walton, W. R. 1950. Ecology of marsh and bay foraminifera, Barnstable, Massachussetts. American Journal of Science, 248: 274-294.

Pujos, M. 1971. Foraminifères et thecamoebiens de la Gironde: leur interêt dans la mise en évidence des biotopes estuariens. Compte Rendus de l'Académie de Sciences de Paris, 273: 1095-1097.

ScotT, D.B. \& Medioli, F.S. 1980. Quantitative studies of marsh foraminiferal distribution in Nova Scotia: implications for sea level studies. Cushman Foundation for Foraminiferal Research, sp. pub. 17, 58 pp.

Scott, D.B., Medioli, F.S. \& Schafer, C.T. 2001. Monitoring in coastal environments using foraminifera and thecamoebian indicators. Cambridge Univ. Press, $177 \mathrm{pp}$.

SEN GUPTA, B. 2002. Foraminifera in marginal marine environments. In: Sen Gupta, B. (ed.), Modern Foraminifera. Kluwer Academic Publishers: 141-159.

TABORDA, R., \& DiAS, J.M.A. 1991. Análise da sobreelevação do nível do mar de origem meteorológica durante os temporais de 1978 e 1981. Geonovas sp. n. 1: 89-97.

Valente, T., Fatela, F., Moreno, J., Moreno, F., Guise, L. \& PATinha, C. 2009. A comparative study of the influence of geochemical parameters on the distribution of foraminiferal assemblages in two distinctive tidal marshes. Journal of Coastal Research, SI 56; 1439-1443.

VeniCE SYSTEM, 1959. The final resolution of the Symposium on the Classification of Brackish Waters. Archivio di Oceanografia e Limnologia, 11, supplement: 243-248. 